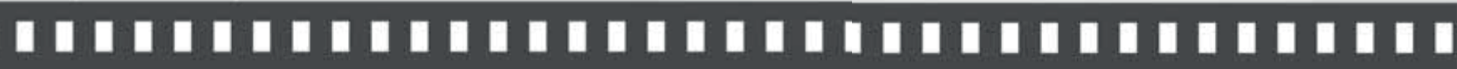

\author{
Resenha: Ensaios sobre a cultura \\ numérica audiovisual
}



\author{
Mateus Dutra Brandao Moreira
}




\section{Ensaios sobre a cultura numérica audiovisual}

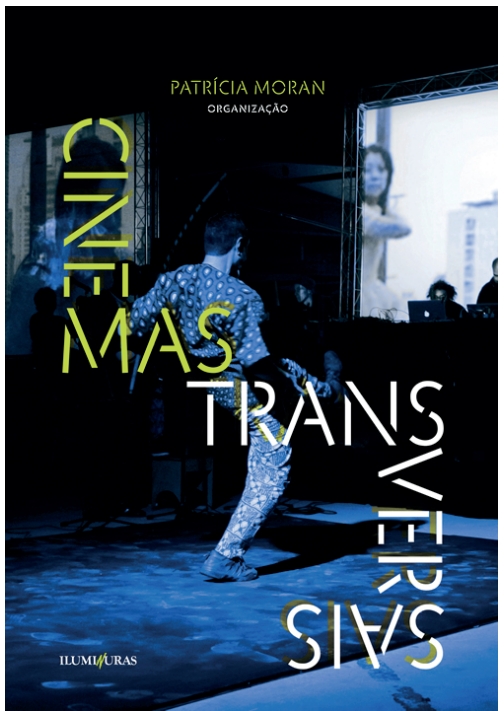

Moran, Patrícia. Org. Cinemas Transversais. São Paulo:

Iluminuras, 2016.

Mateus Dutra Brandao Moreira*

Patrícia Moran é doutora em Comunicação e Semiótica pela PUC-SP, professora e pesquisadora no departamento de Rádio Cinema eTV daECA/USP.É diretora de cinema e vídeo, já participou de importantes festivais internacionais e nacionais, na atualidade

* Mestre pelo Programa de Pós-Graduação em Arte - Instituto de Artes da UnB (PPG-Arte - Ida/UnB) na área de Arte e Tecnologia. Possui graduação em Comunicação Social pela Universidade Federal de Minas Gerais (2006) e especialização em Imagens e Cultura Midiática pela mesma instituição (2009). Tem experiência na área de Vídeo, com diálogo em Cinema e Artes. 
pesquisa performances audiovisuais em tempo real. Idealizou e coordenou o seminário "Arranjos Experimentais: Cultura Numérica Audiovisual”, evento produzido pelo Laboratório de Investigação e Crítica Audiovisual (Laica), Escola de Comunicações e Artes, Programa de Pós-Graduação em Meios e Processos Audiovisuais e pelo departamento de Cinema, Rádio e Televisão da Universidade de São Paulo.

O livro "Cinemas Transversais", lançado esse ano e editado em São Paulo pela Iluminuras, contém textos organizados por Patrícia Moran com base no seminário "Arranjos Experimentais: Cultura Numérica Audiovisual" que aconteceu em junho de 2013. O Livro reúne investigações de autores e artistas consagrados, sobre práticas artísticas contemporâneas como microcinema, performances audiovisuais, cinema móvel, projeções no espaço público e o hegemônico cinema clássico. Segundo a organizadora, o ponto de partida para o evento, que culminou no livro, são as performances audiovisuais em tempo real.

Segundo Moran, essa poética merece um olhar cuidadoso, não somente por serem pouco estudadas ainda, mas também por estarem em constante conexão com práticas como o cinema clássico e experimental, o cinema expandido, o vídeo, o teatro, lugares onde sempre há o hibridismo entre imagens e sons, gerando trabalhos que confrontam problemas como a relação das obras com o espaço.

Moran nos apresenta um panorama seguro e denso de estudos sobre a relação obra-espaço-interator/corpo.Aorganização dos artigos nos trazem uma reflexão em torno do que está sendo produzido na atualidade, dessa cultura numérica audiovisual que traz reflexões em volta da presença do mundo digital na produção 
imagética ao fazer uso do computador na estética dos trabalhos artísticos. Essas imagens poéticas carecem do aparato durante a representação, convertendo o dispositivo técnico em um membro do processo criativo.

Já no prefácio, a autora informa ao leitor sobre o que vai tratar nas 213 páginas que se seguem. Sem muitos rodeios, Moran detalha capítulo por capítulo, parte por parte. O livro é dividido em 3 partes: a primeira, "Cruzamentos - Novos problemas: Cruzamento de Dispositivos" é composta por textos de Mary Ann Doane, Arlindo Machado e André Parente. A segunda parte, "Experiências e Experimentos", segue com textos de Cornelia Lund, Ana Carvalho, Katia Maciel e Valentina Montero Peña. A terceira e última parte, "Diálogos", é composta por diálogos, entrevistas e leitura de portifólio, com textos de Marcus Bastos, Mia Makela e leitura do portifólio de Steve Dixon por Rubens Rewald.

O livro conta ainda com um posfácio escrito por Esther Hamburger. Nele Hamburger dá seu parecer sobre o seminário Arranjos Experimentais e os textos de Cinemas Transversais, fala do esgotamento do cinema convencional e dos diferentes caminhos experimentais cinematográficos que os textos organizados por Moran trazem.

$\mathrm{Na}$ primeira parte do livro temos três textos, de Doane, Parente e Machado, respectivamente. Neles encontramos as mais diversas vivências audiovisuais. Em "Escala e corpo no e para além do cinema", Doane traça um paralelo de escalas das gigantes telas Imax aos smarphones, trabalhando com conceitos de esvaziamento das imagens, hoje hegemonicamente mercantilizadas. Paralelo a isso, analisa a obra de Jim Campbell poeticamente imersiva 
em que o corpo integra a obra. Já Parente traça uma arqueologia sobre o cinema experimental brasileiro, marcado pela pluralidade e resistência ao cinema hegemônico. Machado, por sua vez, fala da desmontagem do dispositivo cinematográfico, de obras que rompem com cultura cristalizada do cinema clássico e ao mesmo faz uma crítica ao caminho contrário de muitas obras audiovisuais instalativas que cada vez mais se aproximam do cinema padronizado que conhecemos.

A segunda parte do livro foca em textos mais específicos sobre determinadas poéticas como o de Cornelia Lund, que busca uma definição para música visual. Na sequência, Ana Carvalho escreve sobre a fugacidade das performances audiovisuais ao vivo, em que, o que fica são as partituras sonoras e coloca em xeque a questão da obra só existir enquanto apresentada. Katia Maciel fala sobre o microcinema de João Modé, retomando um pouco a questão de escala que Mary Ann Doane discute. E, finalizando a segunda parte, Montero fala da "mestiça América Latina", da arte experimental como vocação latina e de como as artes midiáticas se apoiaram nos contextos politizados dos países latinos.

A terceira e última parte de "Cinemas Transversais" é dedicada às Performances Audiovisuais e os textos são constituídos praticamente de entrevistas. Segundo Moran, as entrevistas constituem uma maneira de apresentar as estratégias criativas e propostas conceituais dos artistas. Temos uma leitura de portfólio em que Rubens Rewald debate o trabalho de Steve Dixon e entrevistas com Alexandre Roscoe, Almir Almas, coletivo Embolex, entre outros, todas sobre seus processos de criação. No último capítulo dessa parte, Mia Makela, pioneira na realização de 
Cinema ao Vivo, fala do seu processo criativo e discute o cinema contemporâneo.

Apesar dessas entrevistas terem sido feitas em 2013, durante o seminário Arranjos Experimentais, a organizadora defende que o método de entrevista é um espaço de produção de conhecimento, por acreditar que ele expõe o retrato de uma época, ao mostrar os desafios dos realizadores, as estratégias e os horizontes projetados pelas obras.

Moran conclui que, pela pluralidade de autores e campos conceituais abordados, "Cinemas Transversais" provoca a reflexão sobre um universo que se contesta em busca de redefinir fronteiras, extremidades, recorrentes às imagens e sons.

Trata-se, enfim, de um livro que vale a pena ser conhecido tanto por especialistas da área (que nele descobrirão abordagens mais aprofundadas de autores, obras, artistas e de conceitos próprios desse cinema transversal, audiovisual, expandido, multifacetado) quanto por entusiastas (que nele encontrarão um panorama mais geral do que está sendo feito hoje em dia ligado ao audiovisual). 